\title{
Leucocyte migration and cell-mediated immunity in syphilis
}

\author{
K. W. M. FULFORD AND J. BROSTOFF \\ From the Department of Immunology, Middlesex Hospital Medical School, and fames Pringle House, \\ Middlesex Hospital, London
}

Delayed hypersensitivity skin reactions in syphilis have been reported by several authors (Turner and Hollander, 1957). The results have been inconsistent in different series although a delayed reaction has most commonly been found in late active cases.

It is now recognized that delayed skin reactions are manifestations of cell-mediated immunity which has been found to be important in, for example, homograft rejection and resistance to many viral and fungal infections.

Serological and other methods have been available for the study of humoral immunity for many years, but only recently have cell culture techniques allowed the development of a variety of systems for examining cellular mechanisms in vitro. These new techniques raised the possibility of investigating the contribution of such mechanisms both to the pathogenesis of syphilitic lesions and to the development of immunity to treponemal infections. The two techniques that have been most widely used are lymphocyte transformation and leucocyte migration inhibition. This paper will be dealing chiefly with the latter.

Animal experiments have shown that the migration in culture of mononuclear cells derived from a variety of immunologically competent tissues, including lymph node, spleen, and peripheral blood, may be inhibited by the presence of antigen to which the cells are specifically sensitized. This inhibition of migration has been shown to occur with the delayed type of hypersensitivity (Søborg, 1967).

The capillary tube migration system, introduced by George and Vaughan (1962) for use in animals, has been adapted successfully by Bendixen and Søborg (1969) for use with human peripheral blood leucocytes. Søborg (1968) demonstrated that inhibition of migration with this system using Brucella antigen, correlated with positive delayed skin tests

Received for publication September 22, 1972

Presented at the Jubilee Meeting of the M.S.S.V.D. at Glasgow, June 8-11, 1972

Address for reprints: Dr. K. W. M. Fulford, Department of Immunology, Middlesex Hospital Medical School, Arthur Stanley House, Tottenham Street, London, W.1 to the antigen, but not with the titre of agglutinating antibodies. Subsequently, migration inhibition with appropriate antigens has been demonstrated by several authors in various conditions including ulcerative colitis (Bendixen, 1969), Hashimoto's disease (Brostoff, 1970), idiopathic Addison's disease (Nerup, Anderson, and Bendixen, 1969), glomerulonephritis (Bendixen, 1968), tuberculin sensitivity (Federlin, Maini, Russell, and Dumonde, 1971) and in both renal (Smith, Eddleston, Dominguez, Evans, Bewick, and Williams, 1969) and hepatic (Eddleston, Williams, and Calne, 1969) homograft rejection.

\section{Material and methods}

The direct leucocyte migration test was carried out following in general the procedure described by Bendixen and Søborg (1969). $50 \mathrm{ml}$. blood were taken gently into a syringe heparinized with preservative-free heparin. The specimen was allowed to sediment in the syringe either spontaneously or after the addition of 25 per cent. by volume of freshly prepared 3 per cent. pig skin gelatin. The supernatant was expelled into sterile plastic tubes and centrifuged at $125 \mathrm{G}$. for 10 minutes. The cell sediment was washed three times in phosphate buffered saline and re-suspended in fresh Eagle's medium M.E.M. (Wellcome Laboratories) enriched with 10 per cent. foetal calf serum (Flow Laboratories). This medium was used also in the culture chambers. The suspension was aspirated into Hawksley $120 \mathrm{~mm}$. unsiliconized capillary tubes, the ends blocked with 'Sealease', and the tubes then centrifuged at $125 \mathrm{G}$. for 10 minutes. The concentration of the suspension was adjusted by trial and error to give a deposit of cells in the tubes between 1 and $2 \mathrm{~mm}$. deep. The tubes were cut with a diamond stylus just below the surface of the deposit, and the cell-containing portion placed in the culture chambers which were closed with cover slips.

The culture chambers were made by fixing $1 \mathrm{~cm}$. plexiglass rings to glass plates using Araldite. The chambers were siliconized. The rings were arranged in a 5 by 5 square. To each chamber was added enriched medium either alone or with antigen. In most cases five control chambers were set up and five chambers for each 
of four concentrations of antigen, the 25 chambers being distributed as a 'Latin' square. In all cases the patient's cells were set up in parallel with a specimen from a control subject matched for age and sex. The results were read blind.

The plates were incubated for between 18 and $24 \mathrm{hrs}$ at $37^{\circ} \mathrm{C}$. During this period the cells migrated from the ends of the capillary tubes across the floors of the culture chambers forming fans of migration (Fig. 1). The area of each fan was estimated by projecting it onto a piece of paper, drawing round the image, and then cutting out and weighing the paper fan.

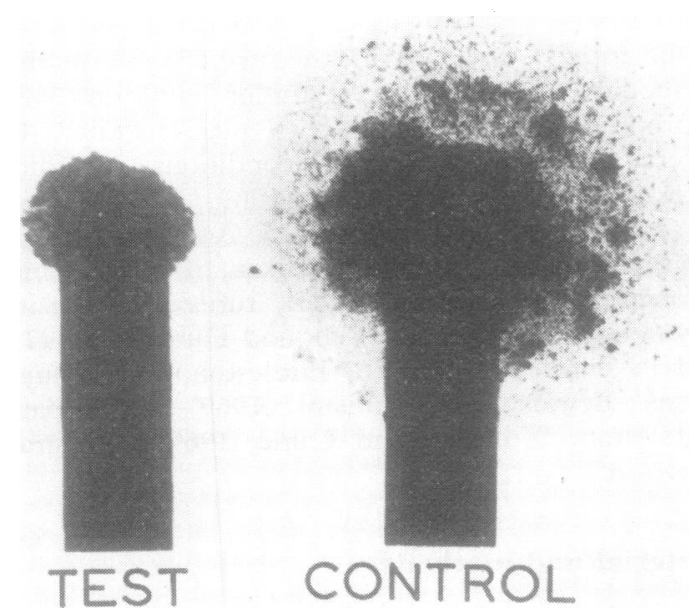

FIG. 1 Leucocyte migration fans. The test field shows inhibition of cell migration in the presence of antigen

The migration index was calculated as the mean of the areas of the fans formed in the presence of antigen divided by the mean of the control areas, the result being expressed as a percentage. Values of more than or less than 100 per cent., therefore, indicated respectively, stimulation or inhibition of cell migration.

In each case, therefore, and for each concentration of antigen, a pair of migration indices was produced, one for the patient and one for the control. The results were expressed as the difference between these pairs. A positive value for the difference indicated that the patient's cells had migrated relatively further in the presence of antigen than the cells from the control subject; that is they showed relative stimulation of migration. A negative value indicated relative inhibition of migration. The results are shown in Figs. 3 to 7 as scattergrams and P-values were calculated using the paired t-test.

The patients were drawn largely from those attending James Pringle House at the Middlesex Hospital, but some specimens were received from other London hospitals. Control subjects were chosen mostly from among the staff, but some were patients from either the department or the main hospital in whom there was no evidence of past or present syphilitic infection. The standard serological tests for syphilis, the absorbed fluorescent treponemal antibody (FTA-ABS) test, and the Treponema pallidum immobilization (TPI) test were performed in all cases.

The antigen used was a freeze-dried preparation of Reiter protein (Ruck Laboratories, Holland) currently in use in the Reiter protein complement-fixation test in the routine laboratory. The preparation used in the test runs was a fresh suspension of the antigen in sterile phosphate buffered saline. The antigen was tested first against cells from several normal subjects. These showed inhibition of migration at concentrations greater than $0.05 \mathrm{mg}$. $/ \mathrm{ml}$. (Fig. 2). This effect was taken to be non-specific, and the concentrations chosen for the test runs were below this range. A dose response of at least three concentrations of antigen was performed in each case.

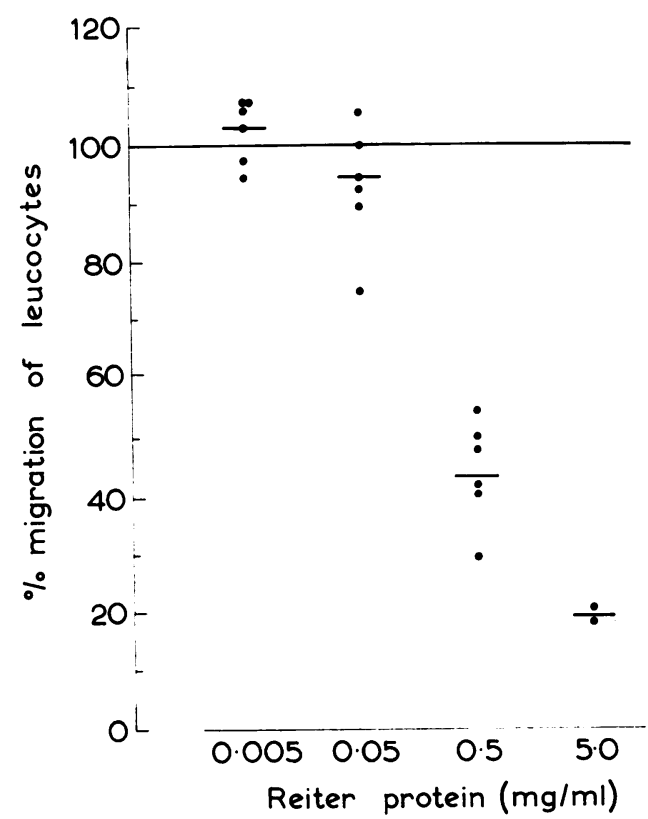

FI G. 2 Dose-response of six normal subjects in the leucocyte migration test to Reiter protein, showing nonspecific inhibition at a concentration greater than 0.05 $m g . / m l$.

\section{Results}

PRIMARY SYPHILIS (Fig. 3, opposite)

Nineteen patients were examined. All had one or more primary chancres. The results are shown with three concentrations of Reiter protein: 0.05, 0.015, and $0.005 \mathrm{mg} . / \mathrm{ml}$. At each concentration there is relative stimulation of cell migration, the results being significant at $\mathbf{P}<0.05$ for the higher and lower concentrations and at $P<0.001$ for $0.015 \mathrm{mg} . / \mathrm{ml}$.

The results showed no significant correlation with the serological tests for syphilis or with various 


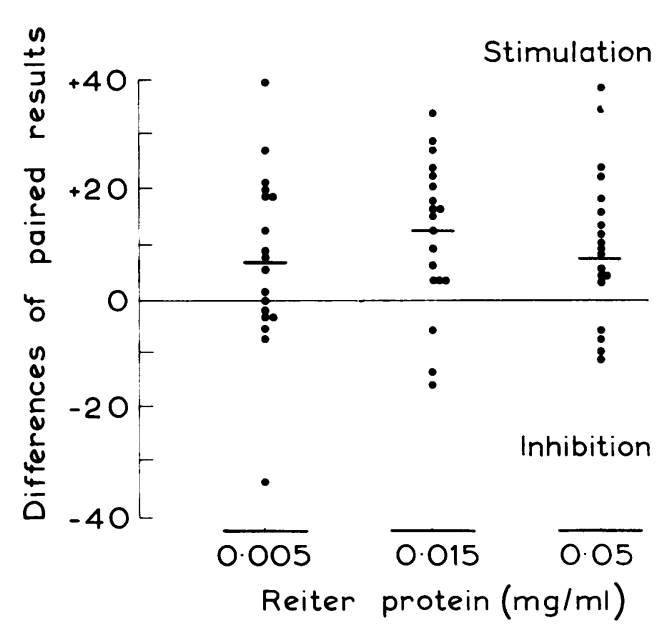

FIG. 3 Primary Syphilis. Leucocyte migration with Reiter protein in patients with primary syphilis and age and sex-matched controls, showing relative stimulation of cell migration

clinical features of the case such as the degree of local lymphadenopathy. There was a tendency for the most marked stimulation to occur with the earliest lesions, but this did not reach statistical significance. This observation, however, raises the possibility of using a test of this sort for very early cases of syphilis, particularly in contact screening before either clinical signs develop or serological tests become positive.

Three further cases have been tested with Reiter protein at a concentration of $0.1 \mathrm{mg} . / \mathrm{ml}$. This would induce a toxic non-specific inhibition of migration in normal subjects but in these cases marked stimulation of migration occurred.

\section{SECONDARY SYPHILIS (Fig. 4)}

In twelve cases of secondary syphilis the results were close to the control values. The scatter was small for this type of test and there was no statistical evidence of either stimulation or inhibition of migration.

Most of the patients had a maculo-papular rash with generalized lymphadenopathy. One had small condylomata and two had mucous patches.

LATENT SYPHILIS (Fig. 5)

The scatter of results in these twelve cases is very wide. There is no significant difference in the pairs overall, but the wide scatter suggests the possibility that with a larger series the patients might segregate into two groups. The numbers are too small for a statistical analysis of the trend, but there is a tendency for the early latent cases to show stimulation of migration and the late latent cases inhibition. It is

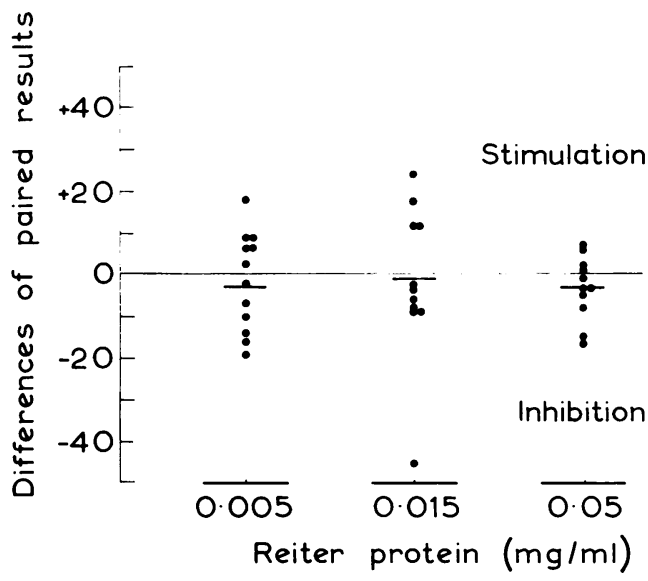

FIG. 4 Secondary Syphilis. Leucocyte migration with Reiter protein in patients with secondary syphilis and control subjects, showing neither stimulation nor inhibition of cell migration

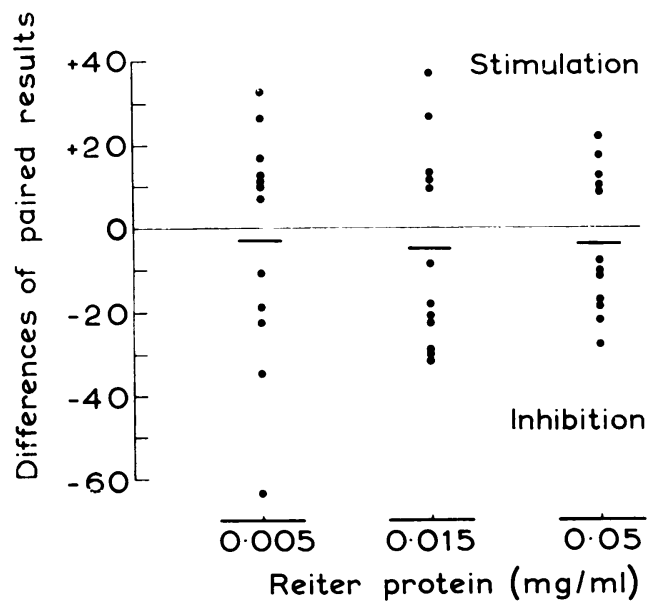

FIG. 5 Latent Syphilis. Leucocyte migration with Reiter protein in patients with latent syphilis and control subjects. In this instance, although there is no significant variation of the mean values from zero, the wide scatter of results suggests the possibility of a bimodal distribution

also of interest that a few patients who had received treatment but who showed persistently positive standard serological tests for syphilis showed stimulation of migration.

LATE ACTIVE SYPHILIS (Fig. 6, overleaf)

The present series included only six cases of late active syphilis. Two patients had neurological signs and symptoms, two had syphilitic aortitis, and two had syphilitic leucoplakia of the oral mucous membrane. 


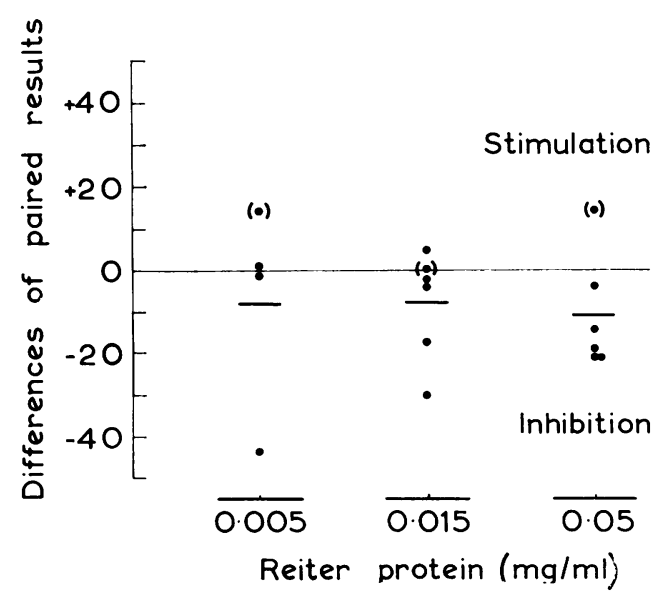

FIG. 6 Late Active Syphilis. Leucocyte migration with Reiter protein in patients with late active syphilis and control subjects, showing inhibition of cell migration. The results in brackets indicate that for this test the control subject, who had multiple sclerosis, showed an abnormal response to Reiter protein. See text and Fig. 7

In all cases the results indicated a marked absolute inhibition of migration. The one case that showed relative stimulation is indicated by brackets round the points on the scattergram. In this case the only available control subject matched for age and sex was a patient with multiple sclerosis who, although a well-authenticated case clinically and with negative standard and specific serological tests for syphilis, showed a marked inhibition of migration with Reiter protein (Fig. 7). This pattern of response was quite unlike the remainder of the results for the control subjects. The patient's cells also responded to a cryolysate of whole treponemes in both migration inhibition and lymphocyte transformation tests.

\section{Discussion}

Stimulation of migration, as observed in the cases of patients with primary syphilis, has been reported in several other instances, for example in liver (Eddleston and others, 1969) and kidney (Smith and others, 1969) organ transplant rejection, and in sensitized guinea-pig spleen cells. Søborg (1968) suggested that stimulation was a low-dose effect; that is, if stimulation occurred at a particular dose of antigen, then inhibition should be seen at a higher dose. Alternatively, stimulation might occur in cells weakly sensitized to an antigen, whereas, if the cells were strongly sensitized, they would show inhibition. The three cases of primary syphilis tested with higher concentrations of Reiter protein, concentrations that

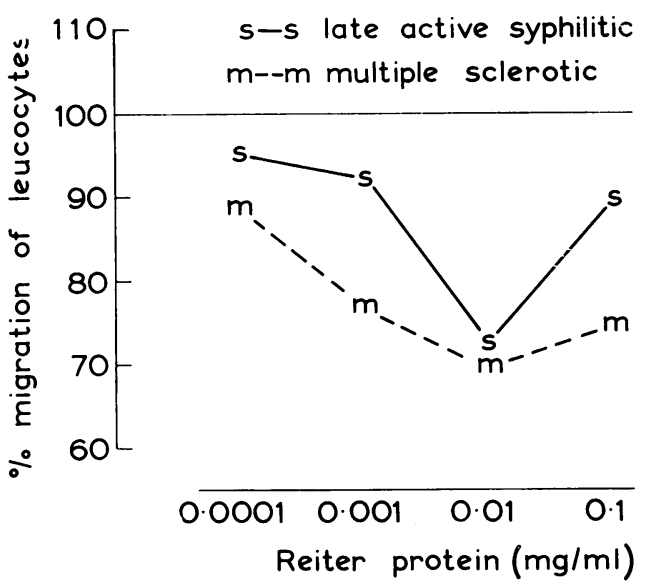

FIG. 7 Leucocyte migration with Reiter protein in a patient with late active syphilis compared with that in a patient with multiple sclerosis. Both subjects show marked absolute inhibition of cell migration across a wide range of concentration of the antigen

would induce a toxic non-specific inhibition of migration in non-sensitized cells, all showed even more marked stimulation. This result suggests that the cells are showing a reaction compatible with weak delayed hypersensitivity.

The absence of response in the migration test in patients with secondary syphilis is in marked contrast to the findings reported with lymphocyte transformation. Several authors, including Chieregato and Faldarini (1968) and Bădănoiu, Gavrilescu, Nicolau, and Circiumăresco (1969) have reported lymphocyte transformation in syphilis, the response being greatest in secondary syphilis both to treponemal antigens and to Reiter protein. Our own series of transformation experiments is small at present, but thus far is consistent with these findings.

Thus, while the transformation reaction is at a maximum in secondary syphilis, the production of migration factors, either stimulating or inhibiting, is absent.

A similar dissociation has been reported by Valdimarsson, Riches, Holt, and Hobbs (1970) in mucocutaneous candidiasis, and it may be taken as evidence of impairment of some part of the immune response. It is relevant in this respect to note the finding of Levene, Wright, Turk, and Grimble (1969) of a serum factor in secondary syphilis that inhibits the phytohaemagglutinin transformation of normal peripheral lymphocytes.

Alternatively, it may be that the cells that transform in secondary syphilis are not in fact involved in 
the delayed hypersensitivity response. Various alternative interpretations have been given to the transformation reaction. It has been shown by Oppenheim (1969) and Möller (1969) that transformation may occur both as a specific and as a non-specific reaction to immune complexes. Another possibility is that transformation represents the reaction of memory cells in either a humoral or a cellular immune response.

A further quite different interpretation of the discrepancy in secondary syphilis between the results in the transformation and the migration tests, is that the cells that produce migration factors are a distinct population from those that transform, and that they are in some way pre-empted into the syphilitic lesions so that they are not demonstrable in the peripheral blood.

The wide scatter of results in the group of latent syphilitics reflects the fact that this group is polymorphous clinically. We would draw attention, however, to the possible clinical applications of the observation that early and treated cases tend to show stimulation and late latent cases inhibition of leucocyte migration.

The inhibition of migration found in the six patients with late active syphilis is evidence for delayed hypersensitivity to Reiter protein determinants in this group. These results are consistent with the positive delayed skin tests reported by several authors (Turner and Hollander, 1957) in patients at this stage of the disease.

Four of these patients were tested against lower concentrations of the antigen, up to a 1,000-fold dilution, and none showed stimulation of migration. This result, taken with the stimulation found in the patients with primary syphilis at higher concentrations of antigen, could be taken as evidence that stimulation and migration are mediated by distinct factors rather than being a function of the concentration of a particular factor.

The result for the patient with multiple sclerosis, both in migration and transformation tests, was an interesting chance finding. Further work is in progress to determine whether patients with multiple sclerosis in general show these reactions.

\section{Summary}

The direct leucocyte migration test was performed on a total of 47 cases of syphilis at various stages, using Reiter protein at several concentrations as an antigen. Stimulation of migration was observed in primary syphilis and inhibition of migration in late active syphilis. This is interpreted as evidence for weak and strong delayed hypersensitivity respectively.
In secondary syphilis neither stimulation nor inhibition of migration was seen. This is in marked contrast to the positive lymphocyte transformation reaction at this stage reported by several authors. The significance of this disparity is discussed. A possible interpretation is that it may represent a failure or suppression of cell-mediated immunity in secondary syphilis. The results in latent syphilis are inconclusive, but the tendency for early and late latent cases to show respectively stimulation and inhibition of migration raises the possibility of distinguishing between them with this test.

The authors thank their many colleagues for their help and advice in the preparation of this paper, particularly Dr. R. D. Catterall, Director, James Pringle House, Middlesex Hospital, and Prof. I. M. Roitt, Department of Immunology, Middlesex Hospital Medical School. We also thank Dr. A. E. Wilkinson, Director, and Mr. J. Storey, Chief Technician, of the Venereal Diseases Reference Laboratory, The London Hospital Research Laboratories, for performing the Treponema pallidum immobilization tests, Mrs. E. Chipperfield, James Pringle House, for carrying out the fluorescent treponemal antibody tests, and Miss F. S. Taylor for her excellent technical assistance.

Dr. K. W. M. Fulford is in receipt of a grant from the Medical Research Council.

\section{References}

BXdÁnolu, A., Gavrilesco, M., Nicolau, G., and Circiumăresco, T. (1969) Arch. roum. Path. exp. Microbiol., 28, 419

BendiXen, G. (1968) Acta med. scand., 184, 99

- (1969) Gut, 10, 631

—_ and SøвоRg, M. (1969) Dan. med. Bull., 16, 1

Brostoff, J. (1970) Proc. roy. Soc. Med., 63, 905

Chimregato, G., and Faldarini, G. (1968) Minerva Derm., 43, 264

Eddleston, A. L. W. F., Williams, R., and Calne, R. Y. (1969) Nature (Lond.), 222, 674

Federlin, K., Maini, R. N., Russell, A. S., and Dumonde, D. C. (1971) f. clin. Path., 24, 533

George, M., and Vaughan, J. H. (1962) Proc. Soc. exp. Biol. (N.Y.), 111, 514

LeVEne, G. M., WrIGHT, D. J. M., TURK, J. L., and GRIMBLE, A. G. S. (1969) Lancet, 2, 246

MöLlER, G. (1969) Clin. exp. Immunol., 4, 65

Nerup, J., ANDERSEN, V., and BeNDIXeN, G. (1969) Ibid., 4, 355

Oppenheim, J. J. (1969) Ann. Allerg., 27, 305

Smith, M. G. M., Eddleston, A. L. W. F., Dominguez, J. A., Evans, D. B., Bewick, M., and Williams, R. (1969) Brit. med. F., 4, 275

SøвоRG, M. (1967) Acta. med. scand., 182, 167

- (1968) Ibid., 184, 135

TURNER, T. B., and Hollander, D. H. (1957) In 'Biology of the Treponematoses', p. 151. World Health Organisation Monograph Series No. 35 
Valdimarsson, H., Riches, H. R. C., Holt, L., and HoBBS, J. R. (1970) Lancet, 1, 1259

\section{Migration leucocytaire et immunité cellulaire dans la syphilis}

SOMMAIRE

Le test de migration leucocytaire direct a été effectué sur un total de 47 cas de syphilis à différents stades et en utilisant comme antigène la protéine de Reiter à plusieurs concentrations. Une stimulation de la migration fut observée dans la syphilis primaire et une inhibition dans la syphilis tardive en activité. Ceci est interprété comme preuve, respectivement, d'une faible et d'une forte hypersensibilité retardée. Dans la syphilis secondaire il ne fut observé ni stimulation ni inhibition de la migration. Ceci s'oppose nettement à la réaction de transformation leucocytaire dans le sens positif trouvée à ce stade par plusieurs auteurs. On discute de la signification de cette différence. Une interprétation possible est que ceci peut représenter un défaut ou la suppression de l'immunité par mécanisme cellulaire dans la syphilis secondaire. Dans la syphilis latente, les résultats ne permettent pas de conclure mais la tendance dans les cas latents précoces et tardifs de montrer, respectivement, une stimulation et une inhibition de la migration fait apparaître la possibilité, grâce au test condidéré, de distinguer ces deux éventualités. 